\title{
AUTHOR INDEX \\ VOLUME 40 (2014)
}

Chan, K.-W., Ping, T.-Y., Chou, S.-J., Zheng, Z.-J., Yang, W.-C., Lai, J.-M., Lo, D.-Y.,

Chang, C.-C. and Wu, J.-T., Case Report: Treatment of an Elderly Dog with Concurrent

Heart Disease and Acute Uremia by Hemodialysis

Chang, C., see Deng, M.-C.

Chang, C.-C., see Tsai, Y.-C.

Chang, C.-C., see Chan, K.-W.

Chang, C. L.-T., see Chen, K.-S.

Chang, C.-Y., see Deng, M.-C.

Chang, C.-Y., see Tung, Y.-C.

Chang, H.-W., see Tsai, Y.-C.

Chang, P.-C., see Yang, P.-C.

Chang, P.-H., see Chen, M.-H.

Chang, P. H., Chen, Y. C., Hsu, W. L., Chen, M. S. and Chen, M. M., Detection of Non-Granulomatous Lesions of Mycobacterium Species in Cultured Freshwater Hybrid Sturgeon

Chang, S.-C., see Chen, K.-S.

Chang, T.-C., see Chiu, K.-C.

Chang, Y.-C., see Lin, J.-S.

Chang, Y.-P., see Peng, P.-C.

Chen, H., see Liu, S.-S.

Chen, I.-W., see Chen, M.-H.

Chen, K.-S., Chien, K.-C., Huang, Y.-S., Chang, C. L.-T. and Chang, S.-C., Proliferative Effect of Platelet-Rich Fibrin on Canine Bone Marrow-Derived Stromal Cells

Chen, M.-H., Chen, I.-W., Kuo, S.-T., Hsu, W.-L. and Chang, P.-H., Evaluation of a

Bacteriophage-Related Chimeric Marine Virus Associated with Abalone Mortality in

Taiwan

Chen, M. M., see Chang, P. H.

Chen, M.-M., see Huang, T.-M.

Chen, M.-M., see Tu, C.

Chen, M. S., see Chang, P. H.

Chen, Y. C., see Chang, P. H.

Chen, Y.-P., Tseng, C.-H., Lee, S.-H., Chou, C.-H. and Tsai, H.-J., Alterations of DNA

Topoisomerases of Riemerella anatipestifer with In Vitro-Reduced Susceptibility to

Quinolones

2 (2014) $95-100$

3 (2014) 115-121

1 (2014) $37-48$

2 (2014) 95-100

3 (2014) 151-161

3 (2014) 115-121

3 (2014) 163-172

1 (2014) $37-48$

4 (2014) 173-180

2 (2014) $77-82$

3 (2014) 139-143

3 (2014) 151-161

1 (2014) 49-55

4 (2014) 199-207

1 (2014) 63-68

3 (2014) 123-130

2 (2014) 77-82

3 (2014) 151-161

Chia, M.-Y., see Tsai, Y.-C.

Chien, C.-H., see Lin, C.-N.

Chien, K.-C., see Chen, K.-S.

Chiou, H.-Y., see Peng, P.-C.

Chiou, M.-T., see Lin, C.-N.

Chiou, R.-Y., see Tu, C.

2 (2014) 77-82

3 (2014) 139-143

3 (2014) 131-138

2 (2014) 69-75

3 (2014) 139-143

3 (2014) 139-143

1 (2014) 57-62

1 (2014) 37-48

1 (2014) 1-9

3 (2014) 151-161

1 (2014) 63-68

1 (2014) 1-9

2 (2014) 69-75 
Chiu, K.-C., Hsieh, C.-Y., Chang, T.-C., Lin, Y.-C., Hu, S.-C. and Wang, F.-I., Frequent Presence of Porcine Teschovirus Antigens in Visceral and Lymphoid Organs of Nonsuppurative Encephalitic Pigs in the Endemic Field Situation

Chou, C.-C., see Wan, M.-T.

Chou, C.-H., see Chen, Y.-P.

Chou, S.-J., see Chan, K.-W.

Chu, C.-Y., see Liu, S.-S.

Chuang, T.-F., see Liu, C.-C.

Chuang, T.-F., see Lin, S.-C.

Deng, M.-C., Chang, C.-Y., Huang, T.-S., Kuo, S.-T., Tsai, H.-J., Chang, C. and Huang,

Y.-L., The Outbreak of Porcine Epidemic Diarrhea in Taiwan

Hsiao, S.-H., see Tsai, Y.-C.

Hsieh, C.-Y., see Chiu, K.-C.

Hsu, C.-C., see Huang, T.-M.

Hsu, W. L., see Chang, P. H.

Hsu, W.-L., see Chen, M.-H.

$\mathrm{Hu}$, S.-C., see Chiu, K.-C.

Huang, P.-Y. and Lin, C.-T., The Neuroprotective Effects on Retinal Structure by Minocycline in a Rat Model of High IOP Induced Retinal Ischemia Injury

Huang, T.-M., Hsu, C.-C. and Chen, M.-M., Antimicrobial Susceptibility of Fish

Streptococcaceae and Drug Resistance Determinants of Erythromycin- and

Tetracycline-Resistant Lactococcus Isolated in Taiwan

Huang, T.-S., see Deng, M.-C.

Huang, W.-W., Jen, C.-C. and Lee, W.-M., Case Report: Combination of Antithrombotics and Thrombolytics Treatment in a Cat with Distal Aortic Thromboembolism

Huang, Y.-L., see Deng, M.-C.

Huang, Y.-S., see Chen, K.-S.

Jen, C.-C., see Huang, W.-W.

Jeng, C.-R., see Tsai, Y.-C.

Kao, J.-P., see Yang, C.-C.

Kuo, S.-T., see Chen, M.-H.

Kuo, S.-T., see Deng, M.-C.

Lai, J.-M., see Chan, K.-W.

Lee, J.-J., see Wang, S.-L.

Lee, J.-W., see Liu, S.-S.

Lee, L.-H., see Shen, P.-C.

Lee, S.-H., see Chen, Y.-P.

Lee, W.-M., see Huang, W.-W.

Liao, A. T., see Lin, S.-C.

Liao, A. T., see Wang, S.-L.

Liao, J.-W., see Yang, C.-C.

Liao, Y.-C., Wang, M.-H. and Wan, C.-H., Molecular Characterization of a Novel Rat

Parvovirus in Taiwan

Lin, C.-M., see Tsai, Y.-C.

Lin, C.-N., Chien, C.-H., Chiou, M.-T., Wang, J.-W., Lin, Y.-L. and Xu, Y.-M., Development of SYBR Green-Based Real-Time PCR for the Detection of Canine, Feline and Porcine Parvoviruses

Lin, C.-S., see Liu, C.-C.

Lin, C.-S., see Lin, S.-C.

Lin, C.-T., see Huang, P.-Y.

Lin, C.-T., see Liu, C.-C.

1 (2014) 49-55

2 (2014) 101-107

1 (2014) 57-62

2 (2014) 95-100

3 (2014) $123-130$

2 (2014) 89-94

4 (2014) 181-190

3 (2014) 115-121

1 (2014) $37-48$

1 (2014) 49-55

3 (2014) 131-138

3 (2014) 139-143

2 (2014) $77-82$

1 (2014) 49-55

2 (2014) $83-87$

3 (2014) 131-138

3 (2014) 115-121

4 (2014) 209-214

3 (2014) 115-121

3 (2014) 151-161

4 (2014) 209-214

1 (2014) 37-48

3 (2014) 145-149

2 (2014) $77-82$

3 (2014) 115-121

2 (2014) 95-100

4 (2014) 191-198

3 (2014) 123-130

1 (2014) 29-36

1 (2014) 57-62

4 (2014) 209-214

4 (2014) 181-190

4 (2014) 191-198

3 (2014) 145-149

1 (2014) 11-19

1 (2014) 37-48

1 (2014) 1-9

2 (2014) 89-94

4 (2014) 181-190

2 (2014) 83-87

2 (2014) 89-94 
Lin, D.-S., see Lin, S.-C.

Lin, J.-S., Lu, P.-S. and Chang, Y.-C., Citizen Cognition of the Stray Dog Issue in Taipei City: A Case of the Movie Twelve Nights

Lin, S.-C., Chuang, T.-F., Lin, C.-S., Lin, D.-S. and Liao, A. T., Immune Characterization of Peripheral Blood Mononuclear Cells of the Dogs Restored from Inoculation of Canine Transmissible Venereal Tumor Cells

Lin, S.-W., see Liu, S.-S.

Lin, Y.-C., see Chiu, K.-C.

Lin, Y.-L., see Lin, C.-N.

Liu, C.-C., Lin, C.-S., Chuang, T.-F. and Lin, C.-T., Investigation of 201 Cases of Canine Keratoconjunctivitis Sicca in Taiwan

Liu, S.-S., Shen, H.-Y., Lee, J.-W., Lin, S.-W., Chen, H., Yang, C.-D. and Chu, C.-Y., Case Report: A Disease Outbreak of Bovine Respiratory Syncytial Virus in Taiwan

Lo, D.-Y., see Chan, K.-W.

Lu, P.-S., see Lin, J.-S.

Pang, V. F., see Tsai, Y.-C.

Peng, P.-C., Chiou, H.-Y., Wu, P.-H., Chang, Y.-P. and Wang, P.-C., Case Report:

Choroid Plexus Carcinoma in the Posterior Cranial Fossa - Pathological Assessment and Treatment in a Dog

Ping, T.-Y., see Chan, K.-W.

Pintel, D. J., see Wan, C.-H.

Proceedings of the 2014 Joint Autumn Conference of the Chinese Society of Veterinary Science and the Taiwan Association of Veterinary Science and Animal Husbandry (CSVS/TAVSAH)

Riley, L. K., see Wan, C.-H.

Shen, H.-Y., see Liu, S.-S.

Shen, P.-C., Yang, J.-L., Su, B.-S. and Lee, L.-H., Cytokine mRNA Expression in Chicken Experimentally Infected with Different Avian Reovirus Strains

Shieh, H. K., see Yang, P.-C.

$\mathrm{Su}$, B.-S., see Shen, P.-C.

Tsai, H.-J., see Chen, Y.-P.

Tsai, H.-J., see Deng, M.-C.

Tsai, Y.-C., Jeng, C.-R., Chang, C.-C., Hsiao, S.-H., Chang, H.-W., Lin, C.-M., Chia, M.-Y., Wan, C.-H. and Pang, V. F., Differences in the Expression of Innate Immune Response-Modulating Genes in Blood Monocytes Between Subclinically Porcine Circovirus Type 2 (PCV2)-Infected and PCV2-Free Pigs Prior to and After Lipopolysaccharide Stimulation In Vitro

Tseng, C.-H., see Chen, Y.-P.

Tu, C., Chiou, R.-Y. and Chen, M.-M., Cloning, Expression and Preliminary Antigenicity Analysis of Structural Proteins of a Koi Herpesvirus Isolate from Koi, Cyprinus carpio in Taiwan

Tung, Y.-C., Chang, C.-Y. and Wang, F.-I., The Classical Swine Fever Virus LPC Vaccine and E2 Glycoproteins Protect from Challenge with Genotypically Homologous Viruses

Wan, C.-H., see Tsai, Y.-C.

Wan, C.-H., Pintel, D. J. and Riley, L. K., Expression of VP2 Protein of Rat Minute Virus Type 1 (RMV-1) in Recombinant Baculovirus and Its Application to Diagnosis of RMV-1 Infection

Wan, C.-H., see Liao, Y.-C.

Wan, M.-T. and Chou, C.-C., Characterization of Bacterial Adhesion and Biofilm Formation Ability of Livestock-Associated Methicillin-Resistant Staphylococcus aureus Isolated from Swine and Slaughterhouse Wastewaters

4 (2014) 181-190

4 (2014) 199-207

4 (2014) 181-190

3 (2014) 123-130

1 (2014) 49-55

1 (2014) 1-9

2 (2014) 89-94

3 (2014) 123-130

2 (2014) 95-100

4 (2014) 199-207

1 (2014) 37-48

1 (2014) 63-68

2 (2014) 95-100

1 (2014) 21-27

4 (2014) 215-260

1 (2014) 21-27

3 (2014) 123-130

1 (2014) 29-36

4 (2014) $173-180$

1 (2014) 29-36

1 (2014) 57-62

3 (2014) 115-121

1 (2014) $37-48$

1 (2014) 57-62

2 (2014) 69-75

3 (2014) 163-172

1 (2014) 37-48

1 (2014) 21-27

1 (2014) 11-19

2 (2014) 101-107 
Wang, C.-H., see Wang, P.-H.

Wang, F.-I., see Chiu, K.-C.

Wang, F.-I., see Tung, Y.-C.

Wang, J.-W., see Lin, C.-N.

Wang, M.-H., see Liao, Y.-C.

Wang, P.-C., see Peng, P.-C.

Wang, P.-H. and Wang, C.-H., Development of Reverse-Transcription Loop-Mediated

Isothermal Amplification for Avian Leukosis Virus Subgroups A and J

Wang, S.-L., Lee, J.-J. and Liao, A. T., Comparison of Cytological and Histopathological Validation on Fine Needle Aspiration of Superficial Masses

Wu, J.-T., see Chan, K.-W.

Wu, P.-H., see Peng, P.-C.

Xu, Y.-M., see Lin, C.-N.

Yang, C.-C., Liao, J.-W., Yu, Y.-C. and Kao, J.-P., Case Report: Splenic Fibrosarcoma in a Campbell's Hamster

Yang, C.-D., see Liu, S.-S.

Yang, J.-L., see Shen, P.-C.

Yang, P.-C., Shieh, H. K. and Chang, P.-C., The Strategies for the Control and Prevention of Foot-and-Mouth Disease

Yang, W.-C., see Chan, K.-W.

Yu, Y.-C., see Yang, C.-C.

Zheng, Z.-J., see Chan, K.-W.
2 (2014) 109-113

1 (2014) $49-55$

3 (2014) 163-172

1 (2014) $1-9$

1 (2014) $11-19$

1 (2014) 63-68

2 (2014) 109-113

4 (2014) 191-198

2 (2014) 95-100

1 (2014) 63-68

1 (2014) 1-9

3 (2014) 145-149

3 (2014) 123-130

1 (2014) 29-36

4 (2014) 173-180

2 (2014) 95-100

3 (2014) 145-149

2 (2014) 95-100 